\title{
A KORTÁRSI VERSENGÉS ÉS PROBLÉMAMEGOLDÁS JELLEMZŐI SERDÜLŐK KÖRÉBEN*
}

\author{
KASIK LÁSZLÓ ${ }^{1}$ - GUTI KORNÉL ${ }^{2}$ \\ ${ }^{1}$ SZTE BTK Neveléstudományi Intézet \\ ${ }^{2}$ Dr. Farkasinszky Terézia Ifjúsági Drogcentrum, Szeged \\ E-mail: kasik@edpsy.u-szeged.hu; guti.kornel@gmail.com \\ Beérkezett: 2014. október 10. - Elfogadva: 2014. december 20.
}

\begin{abstract}
A vizsgálat célja a kortársakkal kapcsolatos versengés és szociálisprobléma-megoldás kapcsolatának feltárása volt 12, 14, 16 és 18 évesek $(N=850)$ körében. A versengés öt dimenziójának (viszonyulás, idö/gyöztes, esélyesség, szabálybetartás, funkció) jellemzöit egy általunk kidolgozott kérdöívvel (Versengés kérdőiv - KASIK és FÜLÖP, 2013) vizsgáltuk. A szociálisprobléma-megoldás mérésére egy adaptált kérdöívet (Social Problem Solving Inventory - D'ZuRILLA, NEZU és MAYDEU-OLIVARES, 2002) használtunk, amellyel a problémamegoldás pozitív és negatív orientációja, valamint három stílusa (racionalitás, impulzivitás, elkerülés) azonositható. A tanulók önjellemzése mellett a szülők (anyák, $N=850)$ és a pedagógusok $(N=35)$ is értékelték a diákokat ugyanazokkal a kérdöivekkel. Az önjellemzéshez képest a pedagógusok alul-, az anyák felülértékelték a diákokat, a versengésnél leginkább a szabálybetartás, a problémamegoldásnál a pozitív orientáció esetében. Az összevont mutató (három értékelö átlaga) alapján a 12 és a 14, valamint a 16 és a 18 évesek rendelkeznek hasonló jellemzőkkel a legtöbb dimenzió mentén. Jelentős különbségek e két csoport között azonosithatók, például a negatív orientáció és a szabálybetartás az idősebbekre, a pozitív orientáció és a versengés idejének fontossága a fiatalabbakra jellemzöbb. A versengés és a problémamegoldás dimenzióinak kapcsolata az életkorral fokozatosan erösödik.
\end{abstract}

Kulcsszavak: versengés, szociálisprobléma-megoldás, serdülők

\footnotetext{
*A kutatás a TÁMOP 4.2.4.A/2-11-1-2012-0001 azonosító számú Nemzeti Kiválóság Program Hazai hallgatói, illetve kutatói személyi támogatást biztosító rendszer kidolgozása és működtetése országos program címủ kiemelt projekt keretében zajlott. A projekt az Európai Unió támogatásával, az Európai Szociális Alap társfinanszírozásával valósult meg. Kasik László a kutatás és a tanulmány megírása idején Magyary Zoltán Posztdoktori Ösztöndíjban részesült.
} 
A versengés és a személyközi problémák megoldásának módja, illetve a változásukat befolyásoló mediátor- és moderátorváltozók köre egyaránt a nevelés- és szociálpszichológia, valamint a pedagógia régóta vizsgált területe (FÜLÖP, 2010; KASIK, 2006, 2014). Kevesebb kutatás foglalkozik a versengés és a szociálisproblémamegoldás kapcsolatával, egymásra gyakorolt hatásukkal, összefüggésük életkori alakulásával. A bemutatott felmérés során a versengés és a problémamegoldás néhány dimenziójának életkori jellemzőit és kapcsolatukat tártuk fel 12, 14, 16 és 18 évesek körében. Az eredmények alapját képezik egy 2015-ben induló programfejlesztési munkának, melynek célja a problémamegoldás komplex, más területekkel együtt történő iskolai fejlesztése. Az elméleti bevezetőben a versengés vizsgált dimenzióiról, a problémamegoldás részfolyamatok szerinti értelmezéséről, valamint e két jelenség néhány serdülőkori sajátosságáról lesz szó. Ezt követően ismertetjük a felmérés célját, módszerét, majd az eredményeket és azok értelmezését.

\section{ELMÉLETI HÁTTÉR}

\section{A versengés dimenziók szerinti értelmezése}

Napjainkban a versengés sajátosságainak feltárására nagymértékben jellemző a komplexitásra törekvés. Az 1990-es évektől - a korábbi évtizedekkel ellentétben, lásd például Deutsch versengésről, a versengés és az együttműködés ellentétéről való elképzelését (FÜLÖP, 2007) - egyre inkább az vált fontos kutatási kérdéssé, milyen kulturális, társadalmi, gazdasági körülmények mellett milyen versengés alakul ki egyének és csoportok között; egyén és csoport szintjén miként fonódik össze más viselkedésformákkal; illetve a versengés milyen szerkezeti, strukturális jellemzőkkel bír. Mindezek együttesen határozzák meg a versengési folyamatok értelmezését, tehát a komplexitás a versengés körülményeinek, lehetőségeinek, más viselkedésformákkal való összefüggésének és struktúrájának együttes figyelembevételét jelenti.

FÜLÖP (1995, 2001, 2008) szerint a versengés olyan - belső késztetésből és/vagy külső környezeti követelményből származó - interakciós folyamat (egyének és csoportok között egyaránt), amely során két vagy több személy valamilyen, számára jelentőséggel bíró cél elnyeréséért adott területen elsőbbségre akar szert tenni. Ellentétben a korábban gondoltakkal, a versengés szerinte nem egydimenziós, hanem több dimenzióból álló jelenség, elemzése több szempont mentén lehetséges. A következőkben a kutatásunk során vizsgált dimenziók jellemzőit mutatjuk be.

NAGY (2000) - alapul véve etológiai kutatások (CSÁNYI, 1994; FISKE, 1992) eredményeit - a versengés három dimenzióját különíti el: szabályozottság, esélyesség, arányos kockázat. A szabályozottság a versengésre vonatkozó szabályok betartását, a betartásra való törekvést jelenti. Esélyesség - FÜLÖP (2001) szerint esélyegyenlőség - esetén a felek tisztában vannak azzal, hogy versengés csak esélyesek között jöhet létre, és fontos, hogy ehhez külső kontroll nélkül is tartsák magukat. Az arányos kockázat annak tudata, hogy esélytelen helyzetben a versengőnek nem érdemes értelmetlen, vakme- 
rő lépéseket tenni. E hárommal szoros kapcsolatban áll a kontrollálhatóság (FüLÖP, 2001, 2003), vagyis mennyire tudják a felek maguk irányítani a versenyhelyzetet, mennyire függ versengésük külső tényezőktől. Fontos, hogy tudják és képesek legyenek szabályozni a folyamatot, ügyeljenek az esélyegyenlőségre, képesek legyenek megakadályozni azt, ha sérül a fair play, illetve ha valaki olyan eszközök alkalmazására kényszerül, ami miatt már nem konstruktív, hanem destruktív a versengés.

A versengés ideje meghatározza a nyertes és a vesztes kapcsolatát (FüLÖP, 2001, 2003). Az idő befolyásolja a versengés folyamatát, mennyi ideig lehetséges a versengés és a versengők milyen időperspektívában gondolkodnak: rövid vagy hosszabb, hosszú távú folyamatként értelmezik a versengést. A rövid távú versengésnél hamar kiderül és egyértelmű, ki a nyertes, ki a vesztes, míg a hosszú távúnál ezeknek kisebb a jelentősége, a versengés ön- és a másik fejlesztő szerepe, hatása kerül előtérbe.

Ugyancsak fontos, kire irányul a versengő figyelme és milyen eszközökkel verseng (FÜLÖP, 1995, 2001). Az önfejlődést szolgálja a versengő önmaga középpontba állítása, konstruktív versengést megvalósítva ezzel, akárcsak akkor, ha a versengés során proszociális tevékenység jellemzi az egyént, amivel hozzájárul a másik fél versengés közbeni fejlődéséhez is. Ha a versengés eszközei leginkább a másikra irányulnak, a cél az, hogy ezáltal a másik hátrányos helyzetbe kerüljön, a versengés destruktív. Mindkét esetben fontos, milyen érzésekkel, motivációs bázissal vesznek részt a felek a folyamatban: mit éreznek a másik iránt, milyen szerepet tulajdonítanak maguknak és a másiknak, milyen eszközök alkalmazását tartják például szükségesnek vagy kerülendőnek. A versengés irányultságával, eszközeivel kapcsolatban fontos szempont a versengés intenzitása is (FÜLÖP, 2001), amit a versengési folyamatok érzelmi háttere, a versengés gyakorisága és annak célja határoz meg leginkább.

Bár a dimenziók szerinti értékelés pontosabb képet nyújt a versengési folyamatról, az értékelés során számolni kell a versengés és ezen belül az egyes dimenziókat jelölő fogalmak egyéni, szubjektív értelmezésével. Már magát a versengést is sokféleképpen értelmezhetik a gyerekek és felnőttek. SÁNDOR (2009) kutatásai alapján kisiskolás korban jól ismert a verseny, a győzelem és a vesztés fogalma, azonban ezeket strukturálisan, versenyként értelmezik (például sportverseny), a társas összehasonlításon alapuló versengés fogalma ekkor még csak alakulóban van, a serdülőkortól válnak igazán külön a fogalmak értelmezései.

\section{Szociálisprobléma-megoldás - részfolyamatok szerinti értékelés}

A személyközi problémák megoldásának értelmezésében is fordulópontnak tekinthetők az 1960-as években lezajló tudományos változások: a személyközi probléma egyéni meghatározását, azonosítását beemelték a problémamegoldás folyamatába, illetve a gondolkodási folyamatot részfolyamatokra bontották a pontosabb értelmezés érdekében (KASIK, 2015). Az a behaviorista felfogás, miszerint a személyközi probléma kizárólag valamilyen negatív helyzet, esemény, viszony lehet, aminek a viselkedésbeli megváltoztatása a cél, valamint az egyén erőfeszíté- 
seinek formái - a problémamegoldás stílusai - a viselkedéséből pontosan meghatározhatók, több szempontból is megdőlt a kognitív pszichológiai, majd az érzelmekkel kapcsolatos kutatások eredményeinek hatására.

Az elmúlt 50 év vizsgálatai (például Chang, D’Zurilla és SANna, 2004; D'Zurilla és Goldfried, 1971; D’Zurilla, Nezu és Maydeu-Olivares, 2002; FRAUENKNECHT és BLACK, 2009) meggyőzően bizonyítják, hogy személyközi problémáink megoldási folyamata már a probléma azonosításával megkezdődik. A szociálisprobléma-megoldás olyan kognitív-emocionális (gondolkodási) és viselkedéses folyamat, amelynek célja egy múltbéli, a jelenben zajló vagy a jövőben lehetségesen bekövetkező probléma megoldása, amelyben a probléma értelmezése szubjektív, nagymértékben függ a tapasztalatoktól (FRAUENKNECHT és BLACK, 2009). A gondolkodási folyamat több részfolyamatra osztható, ezekben számos érzelmi és kognitív tényező - egymással bonyolult hálózatot alkotva - fontos szerepet játszik, illetve a folyamat és a végkimenetel viselkedésben is megnyilvánulhat. A következőkben a problémamegoldó folyamatot leíró modellek közül azt ismertetjük, amely az általunk használt mérőeszköz kidolgozásának az alapjául szolgált.

A viselkedés döntési és kivitelezési szakaszokra való felbontása (például Damasio, 1994) alapján D'Zurilla, Nezu és Maydeu-Olivares (2002) a problémamegoldó folyamat orientációs és megoldási szakaszát különítették el. Az orientációs szakaszban gondolkodásunk többnyire két, egy pozitív és egy negatív dimenzió mentén zajlik. A pozitív dimenzión belül öt aldimenzió különül el: 1. a probléma kihívásként való értelmezése; 2 . a problémamegoldás optimista megközelítése; 3. az énhatékonyság és a megoldás közötti kapcsolat pozitív minősítése; 4. a megoldásra fordított idővel és a befektetett energiával kapcsolatos pozitív gondolatok; 5. az énbe vetett hit arra vonatkozóan, hogy szükség van a megoldásra, azt nem lehet elkerülni. A negatív dimenzió három aldimenziója a pozitív dimenzió három kategóriájával - 2., 3., 4. - áll szemben: 1. a problémamegoldás pesszimista megközelítése; 2. az énhatékonyság és a megoldás közötti kapcsolat negatív minősítése; 3. a problémamegoldással járó frusztráció nem hatékony kezelése (MAYdeu-Olivares és D'Zurilla, 1996).

A problémamegoldó szakasz négy részből áll: 1. a probléma definiálása, 2. alternatív megoldási módok keresése, 3. annak eldöntése, ezek közül adott helyzetben melyik lehet a legalkalmasabb és 4. ennek értékelése a következmény, a kapcsolat további alakulása szempontjából. D'Zurilla, NeZu és MAYDEU-Olivares (2002) e részek alapján három általános problémamegoldói stílust különítettek el: 1. racionális; 2. impulzív és 3. elkerülő, amelyek a problémamegoldó gondolkodás eredményeként megnyilvánulhatnak a viselkedésben, vagyis ezek viselkedési stratégiáknak is tekinthetők. A racionális problémamegoldó a tényeket helyezi előtérbe és azokat mindvégig középpontban tartja; az impulzív a megoldást segítő tények közül csak néhányat vesz figyelembe, negatív érzelmei erőteljesen befolyásolják a tények kiválasztásában és a megoldás kivitelezésében; végül az elkerülő a megoldást a szükségesnél hamarabb fejezi be, illetve azt másokra hárítja vagy el sem kezdi, gyakran negatív érzelmekkel fütött a gondolkodása. A szerzők szerint mindenkinél megállapítható a tipikus stílus (általános stílus), illetve egy-egy hely- 
zetben tanúsított viselkedésben fóként egy dominál, ugyanakkor a probléma természete és a helyzet sajátosságai nagymértékben befolyásolják azt, ezáltal a stílusváltás vagy a kettős, hármas stílusdominancia lehetséges (lásd KASIK, 2015).

\section{A versengés és a problémamegoldás néhány serdülőkori jellemzője és kapcsolata}

A serdülőkor kitüntetett időszak a versengés alakulásában, a korábbi évekhez képest a versengés a társas összehasonlítás egyik nagyon fontos elemévé válik (FÜLÖP, 2007). Igen gyakori a nyílt szabályok szerinti, sokszor csoportos versengés, és körükben egyre fontosabbak az íratlan szabályok is, az azok mentén történő versengés. Szintén nagyon fontosnak tartják a sportszerű, fair play szerinti versengést, igénylik a szabályok közös kialakítását és azok betartását (FÜLÖP, 2001). KASIK (2010) vizsgálata alapján a versengés és az együttműködés esetében is a csoportból való kizárás egyik legfóbb oka a szabályok megszegése. VAN AVENMART (1996) kutatásai alapján a serdülőkorúakra az egyre intenzívebb versengés jellemző, vagyis a versengésnek az intenzitáson belül értelmezett gyakorisága nő.

Hasonlóan jelentős időszak a serdülőkor a szociálisprobléma-megoldás spontán változásában is, 7-12 éves kor között kevésbé intenzív a változás, mint a serdülőkorban. HigGins és THIEs (1981) azt tapasztalták, hogy 10-12 éves korban minél több megoldási lehetőséget vettek számba a diákok, annál hatékonyabb volt problémamegoldásuk, illetve annál jobban kezelték a problémamegoldással járó negatív érzelmeket. Több vizsgálat alapján a 7-12 évesek pozitívabban viszonyulnak társas problémáikhoz, jobban hisznek a megoldás lehetőségében, mint a serdülőkorúak, ugyanakkor kevésbé pontosan definiálják a problémát, mint a serdülők (SPIVACK és SHURE, 1976). Serdülők (12-16 évesek) és fiatal felnőttek (20-24 évesek) problémamegoldásának összehasonlítása alapján a serdülőkor elejétől egyre kisebb mértékű a problémák sikeres megoldásába vetett hit, ami nagyfokú függetlenséget mutat a probléma természetétől (D’ZuRILLA, MAYDEU-OLIVARES és KANT, 1998).

RUBin és ROSE-KRASNOR (1992), valamint WEBSTER-STRATTON (1988) szerint gyermek- és serdülőkorban egyaránt a személyközi problémák természetének és megoldásuk módjának kiemelt szerepe van abban, milyen más társas tapasztalatokat szereznek a diákok osztályukban és más csoportokban. A diákok problémamegoldási stílusa a csoport szerveződését, a tagok viszonyát, kortársaik körében való kedveltségüket igen nagy mértékben, pozitívan és negatívan egyaránt befolyásolhatja.

Azok a serdülők, akik személyközi problémáik megoldása során több alternatív lehetőséget képesek felsorakoztatni, több ötletük van a probléma megoldására, azok szintén több - ám nem feltétlenül kedvezőbb, jobb - együttmüködési és versengési stratégiát működtetnek társaik körében. A hatékony problémamegoldó stratégiákat alkalmazó diákok kedveltebbek és kevesebb agressziót mutatnak frusztrált és versenyhelyzetekben, mint a nem kedvelt diákok (például ROSETH, JOHNSON és JOHNSON, 2008; Rubin és DANiEls-Bierness, 1983; WebSTER-STRATtOn, 1988). 
A versengés és egy-egy versenyhelyzet egyaránt lehet személyközi probléma forrása, akárcsak a verseny eredménye, kimenetele, az azzal összefüggő gondolatok és érzelmek. A versengés, versenyhelyzet megélése esetében ez kapcsolódik ahhoz, minek tekintik a versenyben részt vevők a versengést, mi motiválja őket: a feladat vagy a másik fél (TASSI és SCHNEIDER, 1997). TASSI és SCHNEIDER (1997) szerint abban az esetben, ha a cél a másik legyőzése, a riválisok között összeütközések alakulhatnak ki, ám akkor kevésbé, ha az a cél, hogy a lehető legjobb eredményt érje el valaki a riválissal való versengés mint eszköz segítségével. A verseny kimenetelének, eredményének feldolgozása szintén eredményezhet problémát, feszültséget, akár nyílt konfliktust is.

\section{AZ EMPIRIKUS VIZSGÁLAT CÉLJA}

Az empirikus vizsgálat célja a versengés és a szociálisprobléma-megoldás életkor szerinti jellemzőinek, valamint a dimenziók kapcsolatának feltárása volt 12-18 évesek körében. A versengés és a problémamegoldás esetében is a kortársakkal kapcsolatos jellemzőket vizsgáltuk (erről részletesen a mérőeszközök ismertetésekor lesz szó).

\section{A MINTA JELLEMZŐI}

A kutatásban 12 és 14 éves általános iskolai, valamint 16 és 18 éves, négy évfolyamos gimnáziumi tanulók ( $\mathrm{N}=850-12: 20,14=210,16=212,18=228)$, illetve szüleik ( $\mathrm{N}=850$, anyák) és pedagógusaik $(\mathrm{N}=35$, osztályfőnökök, nők) vettek részt. A diákok önmaguk versengését és problémamegoldását jellemezték, a pedagógusok és a szülők a diákokat. Az életkori részminták a szülők iskolai végzettsége és a család szerkezete (kivel él a gyermek egy háztartásban) alapján hasonlóak. Sem az anyák, sem az apák végzettsége $(1=$ nyolc általános, $2=$ szakmunkásbizonyítvány, $3=$ érettségi, $4=$ főiskola, $5=$ egyetem) alapján nincs jelentős különbség (anya: $\chi^{2}=21,08 p=0,08$; apa: $\chi^{2}=25,11 p=0,09$ ) a csoportok között, mindegyikben az érettségivel rendelkező anyák (45-57\%) és apák (43-56\%) aránya a legnagyobb. A család összetételét leíró kategóriák közül $(1=$ anyával és apával, $2=$ anyával, apával és testvérrel/testvérekkel, $3=$ csak anyával, $4=$ anyával és testvérrel/testvérekkel, $5=$ csak apával, $6=$ apával és testvérrel/testvérekkel, $7=$ egyéb) a 2-eshez tartozók aránya (37-42\%) a legnagyobb mindegyik almintán $\left(\chi^{2}=17,12 p=0,14\right)$.

\section{MÉRŐESZKÖZÖK, MÉRÉSI ELJÁRÁS}

A felmérés során két mérőeszközt alkalmaztunk, az általunk kidolgozott Versengés kérdốivet (VK; KASIK és FÜLÖP, 2013), illetve a Social Problem-Solving InventoryRevised (SPSI-R; D'Zurilla, NeZu és MAYDEu-Olivares, 2002) adaptált változa- 
tát (SZPMK - Szociálisprobléma-megoldás kérdốvi KASIK, NAGY és FŰZY, 2009). Mindkettőnél gyermeki, szülői és pedagógusváltozatot használtunk, hiszen számos kutatás bizonyítja, hogy gyermek- és serdülőkorúak vizsgálatakor a csak önjellemzéssel szerzett információk megbízhatósága alacsony, ezért érdemes külső értékelőket is bevonni (CHEN, 2006).

\section{Versengés kérdöív}

A versengés hat dimenziójának (viszonyulás, idő, győztes, esélyesség, szabálybetartás és funkció) mérésére fejlesztettük ki a kérdőívet FiSKE (2006), Fiske, (1992), FÜLÖP (1995, 2001, 2010) és NAGY (2000) munkái alapján. Korábbi kutatások és fejlesztőprogramok alapján ezekről véltük úgy, hogy az iskolai, társak közötti versengés értékelésekor nagyon fontosak. A szülői és a pedagógusi változatok kijelentései egyes szám harmadik személyűek. Mind a diákoktól, mind a felnőttektől azt kértük, hogy a kortársakkal kapcsolatos versengés, versenyhelyzetek megítélése alapján töltsék ki a kérdőívet. A kijelentéseket ötfokú skálán kell értékelni ( $1=$ egyáltalán nem jellemző rám $-5=$ teljes mértékben jellemző rám).

A kérdőív eredetileg 35 kijelentésből állt, majd a kismintás mérést követő elemzés során 30-ra csökkentettük az itemek számát, melyek mindegyike pozitív állítást tartalmaz. A mérőeszköz változatainak belső konzisztenciáját jellemző Cronbach- $\alpha$ minden esetben megfelelő ( 0,73 vagy e feletti). A fökomponenselemzés a Kaiser-Meyer-Olkin-mutatók (minden esetben 0,7 feletti) alapján lehetségesnek bizonyult. A várt hat faktor helyett öt faktor különült el, amelyek mindegyike 1-nél nagyobb sajátértékkel rendelkezik: viszonyulás (7 item), idő/győztes (6 item), esélyesség (6 item), szabálybetartás (5 item), funkció (6 item).

A viszonyulás a versengéshez és a versenyhelyzetekhez való viszonyulás jellemzőit mutatja (például Szeretem, ha jobb vagyok valamiben másoknál). Az eredetileg idő és győztes dimenzióhoz tartozó tételek egy faktort alkotnak (idő/gyöztes), mely azt mutatja meg, miként gondolkodnak a verseny idejéről, hosszáról, mikor szeretnék megtudni annak eredményét (például Bármeddig versenyezhetek társaimmal). Az esélyesség tételei a részvétellel és a nyeréssel kapcsolatos esélyességre vonatkoznak, illetve érintik az arányos kockázatot is (például Csak akkor versengek, ha van esélyem a győzelemre). A szabálybetartás tételei a szabályok elfogadására, betartására, a mások által meghatározott előírások szerinti versengésre vonatkoznak (például Versengés közben betartom a szabályokat). A funkció a versengés közbeni tanulással, önfejlesztéssel, önértékeléssel kapcsolatos kijelentéseket tartalmaz (például Versengés közben sokat tanulok másoktól).

\section{Szociálisprobléma-megoldás kérdőí}

Az SPSI-R önjellemzéses, szülői és pedagógusi változatát 2009 óta alkalmazzuk. Megbízhatósági mutatói igen jók (minden változat esetében 0,81 feletti), illetve a kérdőív faktorstruktúrája az eredeti angol eszköz szerkezetével közel megegyező 
(lásd KASIK, 2014). A 25 kijelentésből álló kérdőívvel a problémamegoldás öt dimenziója (pozitív és negatív orientáció, racionalitás, impulzivitás, elkerülés) mérhető. A kijelentéseket ötfokú skálán kell értékelni $(1=$ egyáltalán nem jellemző rám $-5=$ teljes mértékben jellemző rám).

A pozitív orientáció a problémához való pozitív, bizakodó viszonyulást (a probléma megoldható, meg tudja oldani, célként értelmezi, például Meg tudom oldani a problémáimat), a negatív orientáció a problémához és a megoldási folyamathoz való negatív viszonyulást, a megoldáshoz társuló negatív érzelmek kifejezését (például Túl sokat aggódom a problémáim miatt.) mutatja. A racionalitás a tényeken alapuló, a tények kapcsolatait, az ok-okozati összefüggéseket figyelembe vevő döntést és problémamegoldást jelenti (például Megpróbálok minél több megoldási lehetőséget keresni). Az impulzivitás a főként negatív érzelmek alapján történő döntést és megoldást, a negatív érzelmek kifejezését mutatja (például Ideges vagyok problémamegoldás közben). Az elkerülés a helyzet megszakítását, a helyzetből való kilépést fejezi ki (például Húzom-halasztom a problémák megoldását).

A mérőeszközt eredetileg személytől független problémák megoldásának mérésére dolgozták ki. E vizsgálatban szúkítettük a kört, és akárcsak a versengés mérésénél, az utasításban arra kértük a kitöltőket, csak a kortársi problémák megoldására gondoljanak. Ez előrevetíti azt, hogy a külső értékelők - feltehetően másként vélekednek információik alapján a gyerekek kortársakkal kapcsolatos problémamegoldásáról, illetve versengéséről is, ugyanakkor a külső értékelők véleményére mindenképpen szükség van.

\section{HIPOTÉZISEK ÉS EREDMÉNYEK}

A kérdőívek tartalma mellett a korábbi hazai és külföldi mérések adatait, valamint a külső értékelők ítéleteinek eltéréseit is figyelembe véve fogalmaztuk meg a hipotéziseket: 1 . a versengés dimenziói közül a viszonyulás, az esélyesség és a szabálybetartás növekvő, az idő/győztes csökkenő tendenciát (egyre jellemzőbb az életkor előrehaladtával), és a funkció - a pontosan megfogalmazott versengési célok miatt - jelentős változatosságot (nem rajzolódik ki egyértelmű tendencia) mutat; 2. a problémamegoldáson belül a negatív orientáció, az elkerülés és a racionalitás növekvő, a pozitív orientáció csökkenő tendenciát jelez, valamint a vizsgált diákok hasonló impulzivitással bírnak; 3. a dimenziók túlnyomó többségénél az anyák és a diákok értékelése a leginkább, a szülőké és a pedagógusoké a legkevésbé hasonló; 4. a pozitív orientáció, a racionalitás és az impulzivitás alakulásában az életkorral egyre jelentősebb szerepet játszanak a versengés dimenziói (dimenziónként eltérően), a negatív viszonyulás és az elkerülés esetében a magyarázóerejük alacsony.

\section{A versengés életkori különbségei}

Az 1. ábra az összevont mutatók (három értékelő átlaga) szerinti életkori elkülönüléseket szemlélteti (ANOVA, Tukey-b). Bár a mérés keresztmetszeti volt, az érté- 
keket összekapcsoltuk, szemléletesebbé téve a feltételezett változásokat. A hipotézissel ellentétben, az összevont mutatók alapján vagy a 12 évesek és a 14-18 évesek, vagy a 12-14 és a 16-18 évesek különülnek el szignifikánsan az egyes dimenziók mentén.

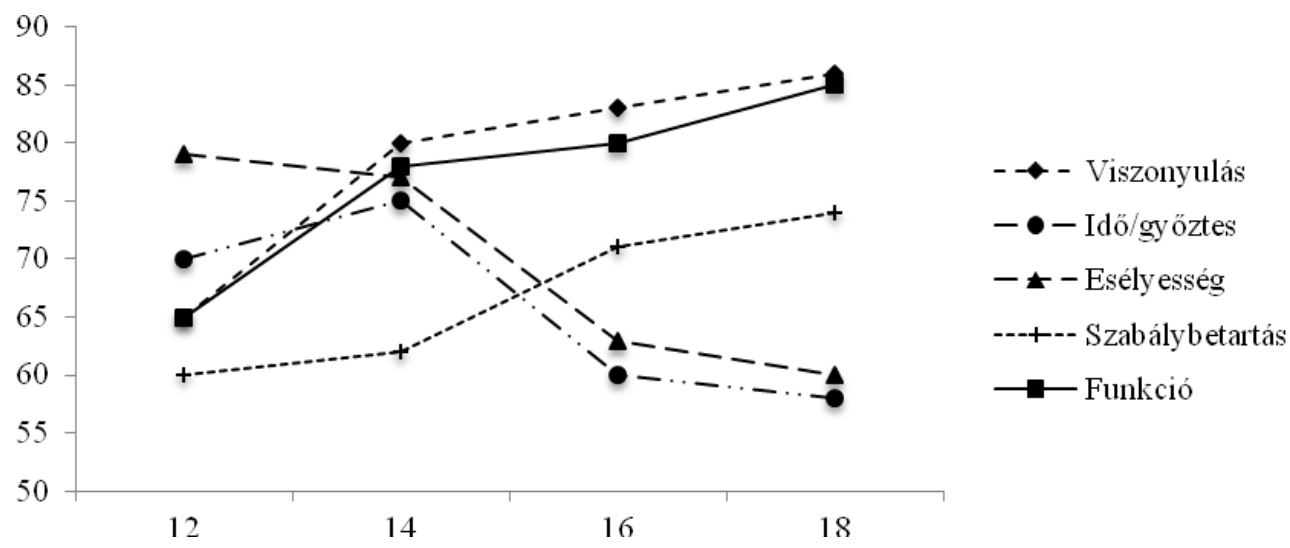

1. ábra. A versengés dimenziók szerinti életkori jellemzői az összevont mutatók alapján (\%p)

Az összevont mutató (1. ábra) alapján a versengéshez való pozitív viszonyulás és a megadott funkciók (például tanulás, önfejlesztés) szerinti versengés a 12 évesekre kevésbé jellemző, mint az idősebbekre (viszonyulás: $\mathrm{F}=65,11 p=0,02$; funkció: $\mathrm{F}=54,01 p=0,03)$. A viszonyulásnál az önjellemzés alapján a 12 és a 14-18 évesek különülnek el $(\mathrm{F}=48,12 p=0,02)$, akárcsak az anyák megítélése alapján ( $\mathrm{F}=49,22 p=0,03)$, ám a pedagógusok véleménye szerint a versengéshez való pozitív viszonyulás a 12 évesekre a legkevésbé jellemző, jobban a 14 évesekre és leginkább a gimnazistákra $(\mathrm{F}=38,23 p=0,04)$. A funkció mentén az önjellemzés és a pedagógusi értékelés alapján ugyanúgy különülnek el a csoportok, mint az összevont mutatók alapján: mind a diákok, mind a pedagógusok értékelése szerint a 14-18 éveseknél fontosabb a tanulást, az önmaga fejlesztését előtérbe helyező versengés, mint a 12-14 éveseknél (önjellemzés: $\mathrm{F}=57,23 p=0,03$; pedagógus: $\mathrm{F}=59,38 p=0,02)$. Az anyák szerint ez a 18 évesekre a leginkább jellemző, a fiatalabbakra egyformán kevésbé $(\mathrm{F}=34,11 p=0,04)$. Az összevont mutató alapján mind az idó/gyöztes ( $\mathrm{F}=60,12 p=0,03)$, mind az esélyesség $(\mathrm{F}=46,10$ $p=0,03$ ) faktoron a 12-14 évesek átlagai szignifikánsan magasabbak, mint a középiskolásoké. Mindkét esetben ezt tükrözik az önjellemzések is (idő/győztes: $\mathrm{F}=47,45 p=0,04$; esélyesség: $\mathrm{F}=55,65 p=0,03$ ): a fiatalabbakra jellemzőbb az a gondolkodás, miszerint bármikor versenghetnek társaikkal és fontos hamar megtudni az eredményt.

Az idő/gyöztes faktornál a szülői értékelés alapján a 12 és a 14-18 évesek között jelentős a különbség, a legfiatalabbakra jellemzőbb, mint az idősebbekre $(F=60,23$ 
$p=0,02)$, a pedagógusok szerint a 12-16 évesekre jellemzőbb, mint a 18 évesekre $(\mathrm{F}=40,21 p=0,03)$. Az esélyesség, az esélyek figyelembevétele a 12 évesekre jellemzőbb, mint az idősebbekre $(\mathrm{F}=56,11 p=0,03)$, a pedagógusok szerint a 12 14 évesekre $(\mathrm{F}=60,34 p=0,02)$. Az anyák értékelése alapján e tekintetben nincs jelentős eltérés a diákok között. A szabálybetartás faktoron a középiskolások nagyobb átlagot értek el, mint az általános iskolások $(\mathrm{F}=47,34 p=0,02)$. Mind a diákok ( $\mathrm{F}=50,10 p=0,03)$, mind a szülők $(\mathrm{F}=44,56 p=0,02)$ értékelése ezt az eltérést mutatja, ám a pedagógusok vélekedése alapján nincs szignifikáns különbség a diákok között.

Korrelációelemzéssel azt vizsgáltuk, milyen kapcsolat áll fenn a három értékelő ítélete között faktoronként és életkoronként. A z-próbák alapján az anyák és a diákok értékelése a leginkább hasonló $(r=0,34-0,59 p<0,05)$, a pedagógus-diák kapcsolatok gyengébbek $(r=0,14-0,40 p<0,05)$, illetve a szülók és a pedagógusok vélekedései a leginkább eltérőek $(r=0,15-0,23 p<0,05)$. A diákok és szüleik a szabálybetartásról vélekednek a leghasonlóbban, legeltérőbben az esélyességről. A pedagógusok és a diákok véleménye a versengés funkciójáról a leghasonlóbb és a viszonyulásról a legeltérőbb. A szülők és a pedagógusok véleménye az idő/győztes dimenzió mentén egyezik a legkevésbé.

\section{A problémamegoldás életkori eltérései}

A 2. ábra a problémamegoldás életkori különbségeit (ANOVA, Tukey-b) szemlélteti az összevont mutatók alapján (az értékeket szintén összekapcsoltuk a jobb áttekinthetőség érdekében). Az eltérések nagyjából megfelelnek a hipotézisnek, igen hasonlóak 12 évesekkel (2009 és 2011 között), valamint 14 évesekkel megkezdett (2012 és 2014 között) longitudinális felméréseink eredményeivel (KASIK, 2014, 2015).

Az összevont mutató alapján (2. ábra) a pozitív orientáció a 12 évesekre jellemzőbb, mint az idősebbekre $(\mathrm{F}=30,22 p=0,01)$, amiről hasonlóan vélekednek a diákok és az anyák (önjellemzés: $\mathrm{F}=28,76 p=0,02$; anya: $\mathrm{F}=33,23 p=0,03$ ), a különbség egyező az összevont mutató szerinti elkülönüléssel. A pedagógusok ítélete alapján nincs szignifikáns eltérés a diákok között. A negatív orientáció a 18 évesekre a legjellemzőbb, legkevésbé a 12 évesekre $(\mathrm{F}=44,20 p=0,02)$. Ezt az elkülönülést mutatja a pedagógusok értékelése $(\mathrm{F}=38,27 p=0,02)$ és a diákok önjellemzése $(\mathrm{F}=32,35 p=0,02)$ is. A szülők szerint a 12-14 évesekre kevésbé jellemző a negatív viszonyulás, mint a $16-18$ évesekre $(\mathrm{F}=27,91 p=0,03)$.

A középiskolásokra jellemzőbb a racionalitás, a tények, összefüggések több megoldási lehetőség mentén történő problémamegoldása $(\mathrm{F}=48,13 p=0,02)$, akárcsak az elkerülés $(\mathrm{F}=37,09 p=0,03)$. A racionalitás a diákok $(\mathrm{F}=35,23 p=0,03)$ és az anyák $(\mathrm{F}=40,17 p=0,02)$ véleménye szerint is jellemzőbb a 16-18 évesekre, a pedagógusok értékelése alapján azonban a legidősebbek racionálisabban oldják meg problémáikat, mint a 12-16 évesek ( $\mathrm{F}=29,33 p=0,03)$. Az elkerïlésról a tanulók $(\mathrm{F}=30,45 p=0,02)$, az anyák $(\mathrm{F}=32,01 p=0,03)$ és a pedagógusok $(\mathrm{F}=20,23 p=0,04)$ hasonlóan vélekednek - ezt szemlélteti az összevont mu- 


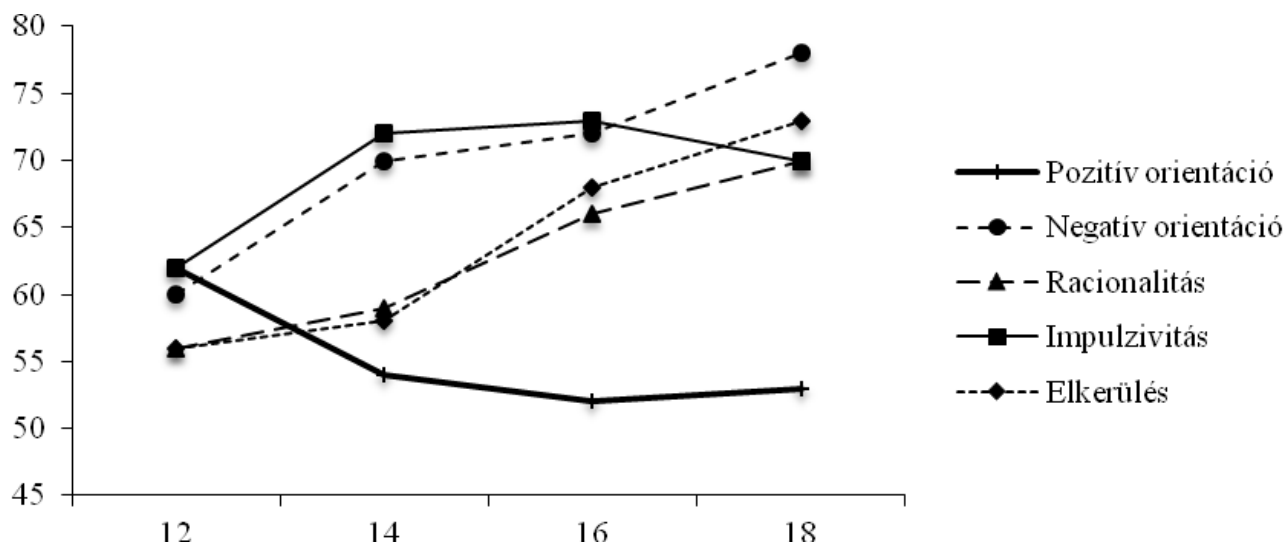

2. ábra. A problémamegoldás dimenziók szerinti életkori jellemzői az összevont mutatók alapján (\%p)

tató szerinti különbség is. Az impulzivitás, az érzelmek és inkább a negatív érzelmek alapján történő döntés és megoldás a 14-18 évesekre jellemzőbb, mint a 12 évesekre $(\mathrm{F}=29,08 p=0,03)$. A diákok szerint ez a 12-14 évesekre jellemzőbb $(\mathrm{F}=27,22 p=0,03)$, mint az idősebbekre, ugyanakkor mind az anyák $(\mathrm{F}=40,11$ $p=0,03)$, mind a pedagógusok ( $\mathrm{F}=30,02 p=0,03)$ szerint a $16-18$ évesekre.

A korrelációelemzés és a z próbák alapján az önjellemzés és a szülői értékelés kapcsolata szinte mindegyik életkorban szorosabb $(r=0,34-62 p<0,05)$, mint a pedagógus-gyermek $(r=0,21-0,41 \quad p<0,05)$ vagy a pedagógus-szülő $(r=0,18$ $0,26 p<0,05)$ kapcsolat. Az anyák és a pedagógusok véleménye a legeltérőbb, leginkább a negatív orientációról vélekednek másként. A diákok és a szülők szintén a negatív orientációt ítélik meg másként, illetve a racionalitás és a pozitív orientáció esetében a legmarkánsabb az egyetértés.

\section{A versengés és a problémamegoldás kapcsolata}

Regresszióelemzéssel vizsgáltuk a dimenziók kapcsolatrendszerét életkoronként (1-4. táblázat). Függő változóként a problémamegoldás öt faktorát, függetlenként a versengés dimenzióit (az önjellemzés adatait) vontuk be az elemzésbe $(r=$ korrelációs együttható; $\beta=$ regressziós együttható; $r * \beta=$ megmagyarázott variancia értéke; $R^{2}=$ összes megmagyarázott variancia; n.s. = nem szignifikáns).

Az összes megmagyarázott varianciák (1-4. táblázat) a pozitív, a negatív orientáció és a racionalitás esetében az életkorral növekvő tendenciát mutatnak, feltehetően a versengés faktorai ezek esetében játszanak egyre fontosabb szerepet. Ezzel szemben az impulzivitásnál és az elkerülésnél az értékek alacsonyak és hasonlóak. A pozitív orientációnál kiemelkedő a versengéshez való viszonyulás és a szabálybetartás, a racionalitásnál az esélyesség és a szabálybetartás hatása. A negatív orientáció, az impulzivitás és az elkerülés esetében a versengésfaktorok magyarázóereje csekély. 

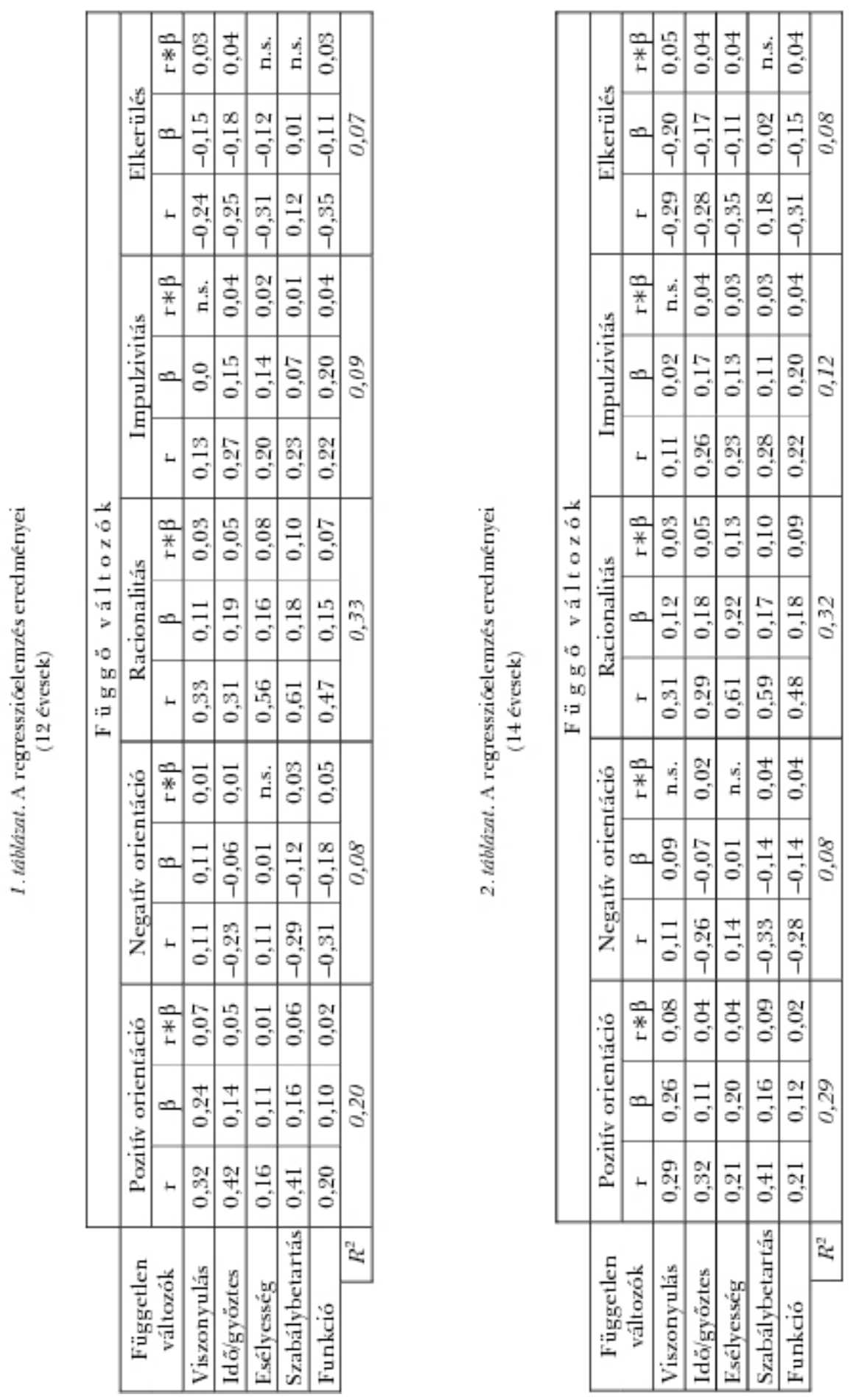

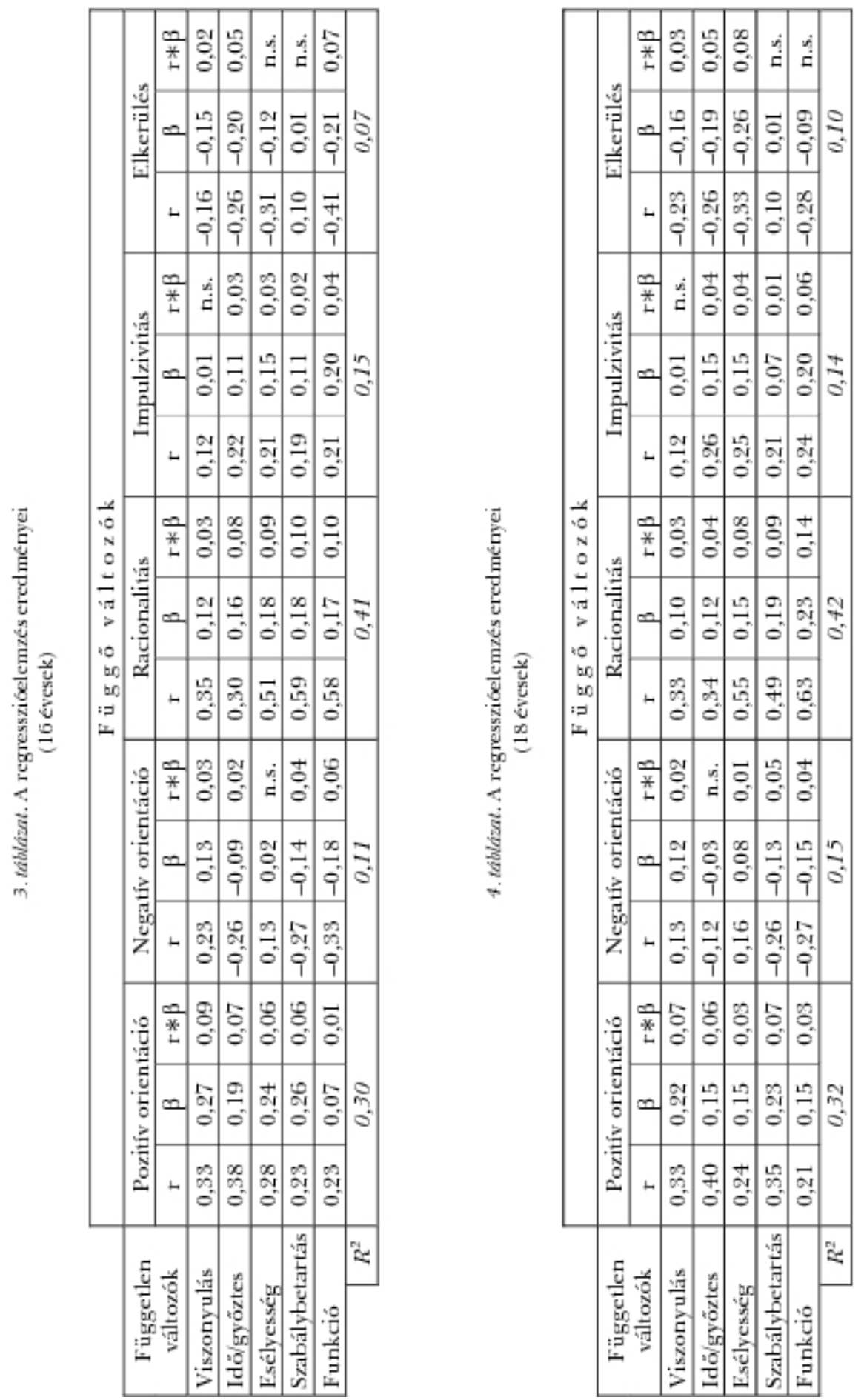


\section{ÖSSZEGZÉS}

A kortársakkal kapcsolatos versengést és problémamegoldást az önjellemzéshez képest az anyák felül-, a pedagógusok alulértékelik. E különbség adódhat az eltérő tapasztalatokból, hiszen a szülők és a pedagógusok más-más helyzetekről, szituációkról rendelkeznek információkkal. Mivel a pedagógusok szórásértékei kisebbek (ez kisebb csoporton belüli egyének közötti különbségre utal), mint a szülők szórásértékei, feltételezhető, hogy a tanárok értékelése a gyerekek összehasonlításán is alapul, az anyáké kevésbé. Az anyák és a tanárnők eltérő véleményének oka lehet az is, hogy utóbbiak értékelésében a pedagógusi szerepkörrel járó elvárások érvényesülnek jobban, az anyáknál az érzelmi alapú döntés, és körükben magas lehet a szociális kívánatosság is (WEBSTER-STRATTON, 1988).

Az összevont mutatók alapján a problémamegoldás leginkább a 12 és a 14-18 évesek között tér el, ám - ahogyan a versengésnél is - az értékelők ítéletei az egyes faktorokon különböznek. Az idősebbekre jellemzőbb a problémához, annak megoldásához való negatív viszonyulás, a racionalitás és az elkerülés, ami megegyezik korábbi kutatási adatainkkal (KASIK, 2014).

A versengéssel kapcsolatban az egyik legfontosabb eredmény, hogy az ahhoz való pozitív viszonyulás és a tanulással, önfejlesztéssel mint funkcióval bíró versengés, az ilyen helyzetben való részvétel szándéka feltehetően erősödik az életkor előrehaladtával. Mindez alátámasztja a serdülőkorra jellemző versengési hajlandósággal kapcsolatos eredményeket (például FüLÖP, 2007). Ugyancsak feltételezhető, hogy minél idősebb diákokról van szó, annál fontosabb a szabályok szerinti versengés. Ennek alakulása számos tényezőtől függ, például ki alakítja a szabályokat; milyen hatások érik őket, amelyek befolyásolhatják a szabályok alakítását és betartását - mindezt érdemes a jövőben részletesen vizsgálni.

Az idő/győztes és az esélyesség alakulása az előzőektől eltérő. A 12-14 évesekre jellemzőbb annak igénye, hogy azonnal megtudják, ki a győztes, illetve körükben többen vélekedtek úgy, hogy csak azzal versengenek, akinek ugyanolyan vagy hasonló esélye van a győzelemre, mint nekik. Ez egyrészt kapcsolatban áll például az önszabályozással, ezen belül a késleltetéssel, ekkortól tovább képesek várni különböző helyzetekre vagy a jutalomra. Az esélyegyenlőség figyelembevétele ugyancsak függ a viselkedésre vonatkozó értékek, normák és szabályok interiorizációjától (például RANSCHBURG, 1984).

A versengés dimenziói leginkább a pozitív orientációt és a racionalitást magyarázzák, a pozitív orientációnál meghatározó a versengéshez való viszonyulás és a szabálybetartás, a racionalitásnál az esélyesség és a szabálybetartás hatása. A pozitív orientáció és a versengéshez való viszonyulás kapcsolatának mértéke nemcsak azt mutathatja, hogy a pozitív viszonyulás hat a problémamegoldáshoz való pozitív orientációra, hanem számot adhat a más tevékenységekkel kapcsolatos pozitív motivációs bázisról is (például szeretném megoldani a problémát - kihívás számomra egy verseny). Ezt az elképzelést erősíti az elkerülés versengéssel való minimális kapcsolata. A racionalitás, a szabálybetartás és az esélyesség összefüggése szintén értelmezhető egy átfogó halmaz mentén: az ok-okozati összefüggések, a következmények végiggondolása, szabályok megfogalmazása, vagyis számtalan 
kognitív tényező múködése fontos mindezekben, ám a racionális problémamegoldás nem azonos a nem érzelmi alapú problémamegoldással, a felsorolásban szereplő műveletek során is közrejátszanak érzelmeink (WEBSTER-STRATTON, REID és HAMMOND, 2001).

Az eredmények számos fontos ismeretet nyújtanak e két terület és kapcsolatuk sajátosságairól. Az adatok megerősítik azon megközelítés fontosságát és szükségességét, miszerint a viselkedésformák alakulásáról, változásáról csak dimenzióik mentén szerezhetünk megbízható információkat.

\section{IRODALOM}

Adrian, M., Lyon, A. R., Oti, R., \& Tininenko, J. (2010). Developmental foundations and clinical applications of social information processing: A review. Marriage and Family Review, 46, 327-345.

Chang, E. C., D’Zurilla, T. J., \& Sanna, L. J. (2004). Social Problem Solving. Theory, Research, and Training. Washington, DC: American Psychological Association.

Chen, K. (2006). Social Skills Intervention for Student with Emotional/Behavioral Disorders: A Literature Review from the American Perspective. Educational Research and Reviews, 3, 143-149.

CsÁnyi V. (1994). Etológia. Budapest: Nemzeti Tankönyvkiadó.

D'Zurilla, T. J., \& Goldfried, M. R. (1971). Problem solving and behavior modification. Journal of Abnormal Psychology, 78, 107-126.

D’Zurilla, T. J., Maydeu-Olivares, A., \& Kant, G. L. (1998). Age and gender differences in social problem solving ability. Personality and Individual Differences, 25, 241-252.

D’Zurilla, T. J., Nezu, A., \& Maydeu-Olivares, A. (2002). Social Problem-Solving InventoryRevised (SPSI-R): Technical manual. North Tonawanda, New York: Multi-Health Systems.

DAmasio, A. R. (1994). Toward a neurobiology of emotion and feeling: operational concepts and hypotheses. The Neuroscientist, 1, 19-25.

Fiske, A. P. (1992). The cultural relativity of selfish individualism: Anthropological evidence that humans are inherently sociable. In M. S. CLARK (Ed.), Review of Personality and Social Psychology, 12: Altruism and Prosocial Behaviour (176-214). Newbury Park: SAGE Publication.

Fiske, S. T. (2006). Társas alapmotívumok. Budapest: Osiris Kiadó.

Frauenknecht, M., \& Black, D. R. (2009). Is it social problem solving or decision making? Implications for health education. American Journal of Health Education, 41(2), 112 123

FÜlÖP M. (1995). A versengésre vonatkozó tudományos nézetek. Pszichológia, 15(1), 61-111.

FülÖP M. (1997). Versengés az iskolában. In MÉSzÁRos A. (szerk.), Az iskola szociálpszichológiai jelenségvilága (172-196). Budapest: ELTE Eötvös Kiadó.

FÜlÖP M. (2001). Az iskolai versengés természetrajza. In SzEkszÁRdi J. (szerk.), Nevelési kézikönyv nem csak osztályfönököknek (123-141). Budapest: Dinasztia Kiadó. 
FÜLÖP M. (2003). A versengés mint szociális készség fejleszthetősége. In ZsOLNAI A. (szerk.), Szociális kompetencia - társas viselkedés (170-192). Budapest: Gondolat Kiadó.

FÜlÖP M. (2007). A sokarcú versengés. In CzIGLER I. és OláH A. (szerk.), Találkozás a pszichológiával (228-259). Budapest: Osiris Kiadó.

FülÖP M. (2008). Paradigmaváltás a versengéskutatásban. Pszichológia, 28(2), 113-140.

FÜlÖP M. (2010). A társas viselkedés szociálpszichológiája: a társas összehasonlítás. In ZsOLNAI A. és KASIK L. (szerk.), A szociális kompetencia fejlesztésének elméleti és gyakorlati alapjai (48-77). Budapest: Nemzeti Tankönyvkiadó.

Higgins, J. P., \& Thies, A. P. (1981). Problem solving and social position among emotionally disturbed boys. American Journal of Orthopsychiatry, 51(2), 356-358.

KASIK L. (2006). A társas viselkedés, a tanulmányi eredményesség és a tanulási-kulturális szokások összefüggése 13-16 éves korban. Magyar Pedagógia, 106(3), 231-258.

KASIK L. (2010). A szociálisérdek-érvényesítő, az érzelmi és a szociálisprobléma-megoldó képességek vizsgálata 4-18 évesek körében. PhD-értekezés. Szeged: SZTE BTK Neveléstudományi Doktori Iskola.

KASIK, L. (2014). Development of Social Problem Solving - A Longitudinal Study (20092011) in a Hungarian Context. European Journal of Developmental Psychology, http://www.tandfonline.com/doi/abs/10.1080/17405629.2014.969702?journalCode=ped p20\#.VGcih_SG_lc

KASIK L. (2015). Személyközi problémák és megoldásuk (kézirat).

Maydeu-Olivares, A. \& D'Zurilla, T. J. (1996). A factor-analytic study of the Social Problem-Solving Inventory: An integration of the theory and data. Cognitive Therapy and Research, 20, 115-133.

NAGY J. (2000). XXI. század és nevelés. Budapest: Osiris Kiadó.

NAGY J. (2010). Új pedagógiai kultúra. Szeged: Mozaik Kiadó.

RANSchburg J. (1984). Szeretet, erkölcs, autonómia. Budapest: Gondolat Kiadó.

Roseth, C. J., Johnson, D. W., \& Johnson, R. T. (2008). Promoting Early Adolescents' Achievement and Peer Relationships: The Effects of Cooperative, Competitive, and Individualistic Goal Structures. Psychological Bulletin, 134, 223-246.

Rubin, K. H. \& DANiels-Bierness, T. (1983). Concurrent and predictive correlates sociometric in kindergarten and grade one children. Merrill-Palmer Quarterly 29, 337-352.

Rubin, K. R. \& Rose-Krasnor, L. (1992). Interpersonal Problem-Solving and Social Competence in Children. In V. B. van Hasselt, \& M. Hersen (Eds.), Handbook of Social Development: A Lifespan Perspective. Plenum, New York.

http://www.rubin-lab.umd.edu/pubs/Downloadable\%20pdfs/kenneth_ rubin/social\%20competence/Hdbk\%20Soc\%20Dev92.pdf

SÁNDOR M. (2009). A versengés, a győzelem és a vesztés fogalma kisiskolás korban. PhDdisszertáció tézisei. Budapest: ELTE Pedagógiai és Pszichológiai Kar. http://pszichologia.phd.elte.hu/vedesek/2010/TzisekMagyar.pdf.

Spivack, G., \& Shure, M. B. (1976). Social adjustment of young children. San Francisco: Jossey-Bass.

TASSI, F., \& SChNEIDER, B. H. (1997). Task-oriented versus other-referenced competition: Differential implications for children's peer relations. Journal of Applied Social Psychology, $27,1557-1580$. 
Van Avenmart, E. (1996). Cooperation and competition. In M. Hewstone, A. S. ManSTEAd, S. T. Fiske, M. A. HogG, H. T. Reis, \& G. R. Serin (Eds.), The Blackwell Encyclopedia of Social Psychology (136-141). London: Blackwell.

WEBSTER-STRATTON, C. (1988). Mothers' and fathers' perceptions of child deviance: Roles of parent and child behaviors and parent adjustment. Journal of Consulting and Clinical Psychology, 56(6), 909-915.

Webster-Stratton, C., Reid, M. J., \& Hammond, M. (2001). Preventing conduct problems, promoting social competence: A parent and teacher training partnership in Head Start. Journal of Clinical Child Psychology, 30(3), 283-302.

\title{
PEER COMPETITION AND SOCIAL PROBLEM-SOLVING AMONG ADOLESCENTS
}

\author{
KASIK, LÁSZLÓ - GUTI, KORNÉL
}

The aim of our research was to reveal any correlation between peers' competition and social problemsolving among 12-, 14-, 16- and 18-year-olds $(N=850)$. Characteristics of the five dimensions of competition (attitude, interval/winner, probability, rule-following, function) have been surveyed by a self-developed questionnaire (KASIK \& FÜLÖP, 2013). We have used an adapted questionnaire to measure social problem-solving (D'ZURILLA, NEZU, \& MAYDEU-OLIVARES, 2002) which is also useful to identify positive and negative orientation in social problem-solving and its three styles (rationality, impulsivity, avoidance). Apart from self-description, mothers $(N=850)$ and teachers $(N=35)$ have also described students with mentioned questionnaire. As compared to students' self-description, teachers have rated them lower and mothers higher, particularly in rule-following in competition and positive orientation in problem-solving. Based on the combined indicators (the average of the three evaluators), it is 12- and 14-, and 16- and 18-year-olds who share characteristics in terms of most dimensions. Major differences can be identified between said groups; for example, negative orientation and rule-following is more typical of the older, while positive orientation and the importance of the competition interval is more characteristic of the younger. The connection between competition and problemsolving becomes stronger with age.

Key words: competition, social problem-solving, adolescents 